\title{
Appropriate Institutions? Traditional Governance and Public Goods Provision in Oaxaca, Mexico*
}

\author{
By Gustavo J. Bobonis, Juan C. Chaparro, \\ Marco Gonzalez-Navarro, and Marta Rubio-Codina ${ }^{\dagger}$
}

Since the mid-1980s, Indigenous populations across the Americas have increasingly demanded and obtained greater autonomy over local affairs (Yashar 2005; Eisenstadt 2011). Indigenous groups in the State of Oaxaca, Mexico have played a prominent role in this movement. In 1995, the state's government reformed its municipal law to recognize the rights of Indigenous groups to use traditional governance institutions in local government affairs through 'Usos y Costumbres' (UyC) legislation (Anaya Muñoz 2005). Since then, more than 400 of the state's $570 \mathrm{mu}-$ nicipalities have become legally administered under this traditional municipal governance system.

This paper examines what changes occurred in Oaxaca's municipalities after the passage of such potentially transformative reform. We combine the 1995 census of UyC electoral and administrative rules with quinquennial population census data of approximately 2,500 Oaxacan localities and annual school level census data to examine changes in political representation and access to public goods, such as electricity, sewerage, and public education, between 1990 and 2005 .

The UyC system's consequences for development have been much debated 11 One of the main

\footnotetext{
* Go to https://doi.org/10.1257/pandp.2020XXXX to visit the article page for additional materials and author disclosure statements.

$\dagger$ Bobonis: Department of Economics, University of Toronto, 150 St. George St., Toronto, ON M5S 3G7, Canada (email: gustavo.bobonis@utoronto.ca); Chaparro: School of Economics and Finance, Universidad EAFIT (email: jcchaparrc@eafit.edu.co); Gonzalez-Navarro: Department of Agricultural and Resource Economics, UC Berkeley (email: marcog@berkeley.edu); Rubio-Codina: Inter-American Development Bank (email: martarubio@iadb.org). We thank Bilver Astorquiza Bustos and Dario Toman for their invaluable research assistance and Christian Dippel for his thoughtful comments. We gratefully acknowledge funding from the Canadian Institute for Advanced Research, the Canada Research Chairs Program, the Social Sciences and Humanities Research Council of Canada (SSHRC) under Insight Grant 435-2014-0764, and the Catholic University of Chile EH-Clio Lab. The views expressed herein are those of the authors and do not necessarily reflect the views of the funding institutions nor those of the IDB, its Board of Directors, or the countries they represent.

${ }^{1}$ To its supporters, it is compatible with democratic functioning as it is based on public participation and consen-
}

sources of restrictions to political representation in Oaxaca's traditional governance regimes is the forced administrative integration of distinct preexisting communities within the state's municipalities. In a large number of $\mathrm{UyC}$ municipalities, the government of the community designated as the municipal capital enjoys the sole decisionmaking authority regarding the allocation of local public goods and services for all residents of the municipality. In approximately 30 percent of localities, residents of outlying communities do not have rights to vote or run for office in municipal elections (Eisenstadt 2011).

The UyC reform and the time elapsed since its implementation allow us to shed light on two key questions regarding the effects of traditional governance systems in Indigenous communities. First, we document that the degree of ethnolinguistic difference between residents of outlying communities and those of municipal capitals is an important predictor of the former's representation in local affairs. That is, because Indigenous municipalities are oftentimes composed of heterogenous groups fragmented along these lines, the reforms can have unintended consequences for Indigenous minorities.

Second, we find that the reform's impact on the provision of public goods is mixed. Villages composed of indigenous minorities are less likely to gain access to electricity than those coethnic to the municipal capital population; however, they are more likely to gain access to sewerage and to public schooling services. This is consistent with a change in the degree of responsiveness of local governments to the needs of outlying communities within customary law regimes, but one that is not necessarily detrimental to communities with weaker political representation. In sum, the evidence suggests that mechanisms of preference elicitation outside of the electoral process are playing an important role in these communi-

sual decision-making (Magaloni, Diaz-Cayeros, and Ruiz-Euler 2019). Critics argue that such institutions may limit political representation because they might disregard standard democratic procedures, gender equality, and human rights (e.g., Recondo 2007; Eisenstadt 2011). 
ties, but concerns remain regarding restrictions on formal representation in municipal affairs.

\section{The "Usos y Costumbres" Reform and Fiscal Decentralization}

The State of Oaxaca implemented the UyC reform in 1995. The reform made official Indigenous communities' traditional governance rules in local elections and administrative affairs 2 The set of municipalities under $\mathrm{UyC}$ was determined in 1995 through a negotiation between state-level representatives and the State Electoral Institute (Recondo 2001).

Governance in $\mathrm{UyC}$ municipalities is based on the principles of communal decision-making, communal service, and the absence of political parties. Governments are composed of a local assembly, which makes the most important budgetary decisions. Citizens are compelled to carry out tasks or duties for the provision of public goods through a traditional "cargos" system, and local leadership can take various forms including elections and rotating appointments. ${ }^{3}$

Formal representation practices vary significantly across communities. According to the 1995 census of UyC municipal governments, governance rules in some municipalities have been adapted to the ideals of representative democracy: universal suffrage, vote secrecy, and the promotion of electoral competition. However, they represent a minority of cases. As highlighted above, an important restriction to political representation is the limited enfranchisement of residents of outlying localities. This is the result of the historical establishment of municipal boundaries throughout the $\mathrm{XIX}^{\text {th }}$ and early $\mathrm{XX}^{\text {th }}$ centuries which overlaid these onto pre-existing historical Indigenous communities organized along ethnolinguistic lines. In 277 out of the state's 570 municipalities, more than two Indigenous groups live under the same municipal jurisdiction.

The UyC reform coincided with the nationallevel fiscal decentralization reforms that started in 1993. Essentially expanding local government

\footnotetext{
${ }^{2}$ Indigenous groups in the state had long deemed this a core demand for which they frequently mobilized. The 1994 Zapatista revolt in the neighboring state of Chiapas prompted the passage of this legislation, in order to maintain political stability and prevent similar uprisings in Oaxaca (Recondo 2001; Juan Martínez 2013).

${ }^{3}$ See Eisenstadt 2011 and Magaloni, Diaz-Cayeros, and Ruiz-Euler 2019 for a detailed discussion of the various dimensions of the forms of traditional governance in this context.
}

resources by a factor of seven, these gave more prominence to municipal authorities in the delivery of public goods and services ${ }^{4}$ This generated a new and unforeseen tension between traditional authorities and municipal residents. In many instances, because traditional authority is vested in the assembly of the municipal capital, only members of those communities can vote and serve as local representatives (i.e., mayors and local assemblypersons). As a consequence, residents of outlying localities can be formally disenfranchised from formal electoral procedures. Specifically, outlying localities that maintained a strong community identity with differentiated systems of communal organization remain subsumed by the municipal governments, but their autonomy is not necessarily recognized in the $\mathrm{UyC}$ system.

\section{Data}

We use three datasets to investigate changes in political representation, public goods provision, and household socio-economic outcomes pre- and post-reform according to the degree of pre-existing ethnolinguistic differentiation in the municipality ${ }^{5}$ The 1995 census was collected to document the governance practices of municipalities governed by UyC (Velásquez Cepeda and Méndez Lugo 1997). It describes the electoral and administrative rules employed in each municipality. We use a dummy variable for municipalities in which residents of outlying communities have rights to either vote or run for office in municipal elections ${ }^{6}$

We also use quinquennial Mexican Population Census data of all Oaxacan localities spanning the period 1990-2005 (INEGI 2010). We measure the ethnolinguistic composition at the locality level in 1990; the share of residents ( 5 and older) who speak each of the main languages of Oaxaca's Indigenous groups.7 Our measure of ethnolinguistic distance between residents of any outlying locality $l$ in municipality $m$ and its mu-

\footnotetext{
${ }^{4}$ Federal transfers per capita increased from $\$ 152$ in 1990 to $\$ 1097$ in 2000 (2010 Mexican Pesos). See Hernandez-Trillo and Jarillo-Rabling (2008) for a discussion of these reforms.

${ }^{5}$ See Bobonis, Chaparro, and Gonzalez-Navarro (2021) for greater details about the data and summary statistics.

${ }^{6}$ The report was published by the Oaxaca State Electoral Institute (IEE) and the Center for Research and Higher Education in Social Anthropology (CIESAS). We thank Todd Eisenstadt for sharing his coding of the $1995 \mathrm{UyC}$ census with us.

${ }^{7}$ The state's main Indigenous groups are Zapotecos, Mixtecos, Mazatecos, Mixes, Chinantecos and Chatinos.
} 
nicipal capital $l^{c}$ is defined as the Euclidean distance of the ethnolinguistic composition of their populations.

Table 1-Ethnolinguistic Distance (ELD) in UyC and Non-UyC Municipalities

\begin{tabular}{lccc}
\hline \hline Mean & All & UyC & Non-UyC \\
ELD for: & $(1)$ & $(2)$ & $(3)$ \\
\hline & & & \\
Outlying & 0.193 & 0.170 & 0.218 \\
Localities & {$[0.264]$} & {$[0.265]$} & {$[0.260]$} \\
Obs. & 5,240 & 2,801 & 2,439 \\
\hline \hline
\end{tabular}

Notes: The measure of ethnolinguistic distance (ELD) between each outlying locality and its corresponding municipal capital foleach outlying locality and its corresponding municipal capital foling localities as well as standard deviation (in squared brackets).

Figure 1. ELD and Political Representation of Outlying Localities' Residents

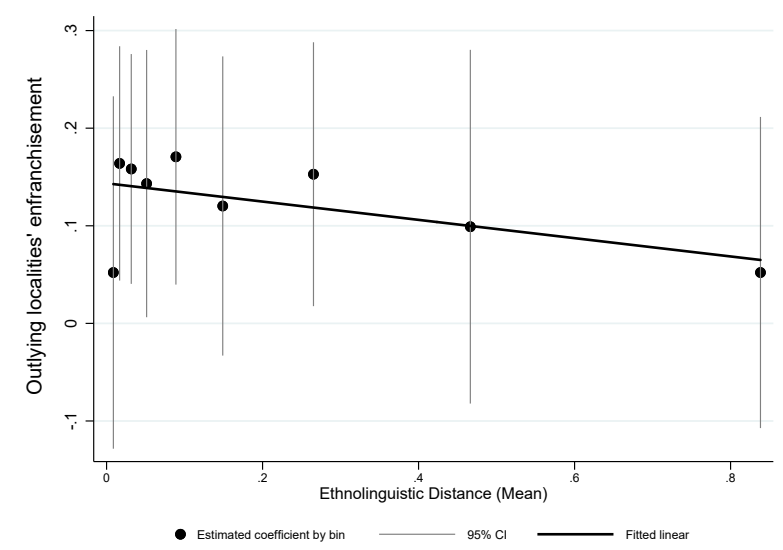

Notes: This figure shows the vector $\beta_{1}$ from an OLS regression of equation (2) with the respective 95 percent confidence intervals; the first decile of the ELD distribution is the omitted category. All regressions contain a control for locality population in 1990, and municipality fixed effects. Standard errors clustered at the municipality level. The straight line represents the fit of the linear model.

Specifically:

\section{(1) $E L D_{l m}=\|$ Idiom $_{l, m}-$ Idiom $_{l^{c}, m} \|$}

where Idiom $_{l, m}$ is the vector of shares of outlying locality residents belonging to each ethnolinguistic group in 1990, and $\operatorname{Idiom}_{l^{c}, m}$ is the analogous vector for municipal capital residents. Table 1 reports summary statistics of our measures of ethnolinguistic distance. The degree of ethnic differences between outlying localities and municipal capitals is slightly lower in $\mathrm{UyC} \mathrm{mu}-$ nicipalities compared to non-UyC municipalities $(\mathrm{p}$-value $=0.043)$. Only 6 percent of outlying localities are perfectly coethnic with municipal capitals in $\mathrm{UyC}$ municipalities.

We also build a locality-level panel of household demographic characteristics, public goods access (i.e., electrification and sewerage rates), and children's literacy rates for the years 1990-2005 using the quinquennial census data. Finally, we use the public schools census conducted annually by the Ministry of Public Education (SEP) from 1990-2002, which allows us to measure locations and characteristics of each school in the state (SEP 2003). We construct an indicator variable for the presence of a secondary school in each locality per year. Our sample consists of 2,801 outlying localities with available census data in the 319 UyC municipalities (out of a total of 418 UyC municipalities) with at least one such locality in addition to its municipal capital.

\section{UyC Reform and Political Representation}

We investigate the relationship between outlying communities' ethnolinguistic differences to residents of the municipal capital and the former's political representation in the UyC system. Figure 1 depicts the semi-parametric relationship from the following model:

$$
\begin{aligned}
y_{l m t}= & \boldsymbol{\beta}_{1} E L D_{l m}^{\prime}+ \\
& \beta_{2} \ln \left(P o p_{l m}\right)+\gamma_{m}+\varepsilon_{l m}
\end{aligned}
$$

where $y_{l m}$ is an indicator variable denoting the enfranchisement of residents of outlying localities in the $(\mathrm{UyC})$ municipality; $E L D_{l m}$ is a vector of indicator variables for each decile of the distribution of ethnolinguistic distance between locality $l$ and municipal capital $m$ in the year 1990; $\ln \left(P_{o p} p_{l m}\right)$ is the logarithm of the locality's population in 1990; and $\gamma_{m}$ represent fixed effects by municipality. Standard errors are clustered at the municipality level. The vector $\beta_{1}$ is the object of interest, which represents the relationship between a locality's ethnolinguistic distance to the municipal capital and its degree of political enfranchisement. These coefficient estimates, together with 95 percent confidence intervals shown as vertical lines, are plotted in Figure 1.

UyC locality residents with greater ethnolinguistic distance to the municipal capital were less likely to be enfranchised following the 1995 UyC political reform (Figure 1). The linear relationship is negative (slope coefficient $=-0.239$ (0.106); p-value $=0.025)$. Localities with the average level of ethnolingustic distance to the municipal capital were approximately 4 percentage points less likely to be enfranchised than locali- 
ties coethnic with municipal capital residents, a 5.7 percent difference in proportional terms.

\section{UyC Reform and Public Goods Provision}

We proceed to study the consequences of the $U y C$ reform for pubic goods provision among outlying localities by estimating the following model:

$$
\begin{aligned}
y_{l m t}= & \theta_{1} E L D_{l m} \times P R E_{t}+ \\
& \theta_{2} E L D_{l m} \times P O S T_{t}+ \\
& \beta \ln (P o p)_{l m t}+\gamma_{m}+\delta_{t}+\varepsilon_{l m t}
\end{aligned}
$$

where $y_{l m t}$ is the public good outcome (i.e., electrification, sewerage, and school provision) in locality $l$, municipality $m$, in year $t$. In this specification, $P R E_{t}$ and $P O S T_{t}$ are indicators that take the value 1 in the period prior and post introduction of the UyC reform in 1995, respectively. The $\theta_{1}$ coefficient captures pre-reform differences in the level of public goods provision of outlying localities with varying degrees of ethnolinguistic differences to the capital within each municipality (i.e., a balance test), and $\theta_{2}$ captures post-reform differences in the gradient between ethnolinguistic distance and public good provision under the $\mathrm{UyC}$ regime. We control for the relevant locality population, and include year $\left(\delta_{t}\right)$ and municipality $\left(\gamma_{m}\right)$ fixed effects; $\varepsilon_{l m t}$ is the error term, clustered at the municipality level.

The consequences of the $\mathrm{UyC}$ reform for the provision of public goods is mixed (Table 2). Villages composed of Indigenous minorities are less likely to gain access to electricity than those coethnic to the municipal capital population (column 1): the point estimate implies that households in localities with the average level of ethnolingustic distance to the municipal capital are approximately 1.3 percentage points (2.4 percent) less likely to have access to electricity than coethnic ones. However, they are more likely to gain access to other public goods: they are approximately 1.0 and 1.3 percentage points (9.7 and 12.3 percent) more likely to have access to sewerage and to middle school facilities than coethnic ones, respectively (columns 2 and 3). Given that non-coethnic localites had somewhat higher electrification rates but had lower access to other public goods than coethnic ones at baseline, these changes in public goods access are consistent with an equalization in the provision of public goods across outlying localities in $\mathrm{UyC}$ municipalities.
Finally, we measure whether these changes in access to public goods translate into improvements in human development outcomes. In particular, we find a modest improvement in the gradient of ethnolinguistic distance and the literacy rates of boys ages 9-11.8 In summary, these results are consistent with a change in the degree of responsiveness of local governments to the needs of outlying communities within the $\mathrm{UyC}$ regime, but one that is not necessarily detrimental to communities with weaker political representation.

\section{Discussion and Conclusion}

There is a growing debate regarding the role of mixed governance reforms - and of the UyC system in particular - for democracy, socioeconomic development, and conflict (e.g., Recondo 2007; Eisenstadt 2011; Magaloni, Diaz-Cayeros, and Ruiz-Euler 2019; see the survey in Holzinger, Kern, and Kromrey 2016). Our findings indicate that, although the reform legitimized the exclusion of minorities from traditional mechanisms of municipal decision-making, they are not necessarily detrimental to these groups. This supports a cautious optimism regarding the reform's welfare implications, in particular because minority groups within $\mathrm{UyC}$ municipalities have started gaining formal recognition in local affairs more recently.

Our findings are of broader interest for policy regarding the governance of Indigenous communities in the Americas. Although a growing number of countries have passed similar legislation, there are limited analyses of their consequences. The experience of Oaxaca suggests that, although local governance is organized along ethnolinguistic lines, it does not necessarily result in the perverse outcomes commonly observed in polarized societies (Padró-i-Miquel 2007; Burgess et al. 2015). Through a better understanding of the reform's implications, this type of work can inform policies to help sustain the devolution of power to Indigenous minorities, and to alleviate social fragmentation and persistent inequality in the region.

\footnotetext{
${ }^{8}$ Boys from households in localities with the average level of ethnolingustic distance to the municipal capital have 1.4 percentage points higher literacy rate than those in coethnic villages, a modest 1.7 percent improvement in proportional terms (Table 2, column 4). We find no effect for girls' literacy.
} 
Table 2-UyC Governance Reform, Ethnolinguistic Differences and Local Public Goods Provision

\begin{tabular}{lccccc}
\hline \hline & $\begin{array}{c}\text { Electrification } \\
\text { Rate } \\
\text { Outcome }\end{array}$ & $\begin{array}{c}\text { Sewerage } \\
\text { Rate } \\
\text { ELD x Pre-Reform }\end{array}$ & $\begin{array}{c}\text { Secondary } \\
\text { School }[1 / 0] \\
(1)\end{array}$ & $\begin{array}{c}\text { Boys' } \\
\text { Literacy } \\
(2)\end{array}$ & $\begin{array}{c}\text { Girls' } \\
\text { Literacy } \\
(5)\end{array}$ \\
\cline { 2 - 6 } ELD x Post-Reform & 0.057 & -0.022 & -0.017 & -0.074 & -0.047 \\
& $(0.071)$ & $(0.021)$ & $(0.030)$ & $(0.054)$ & $(0.046)$ \\
ln (Population) Control & $-0.078^{*}$ & $0.056^{* *}$ & $0.074^{* *}$ & $0.082^{* * *}$ & 0.024 \\
Municipality Fixed Effects & $(0.041)$ & $(0.024)$ & $(0.033)$ & $(0.031)$ & $(0.029)$ \\
\cline { 2 - 6 } Year Fixed Effects & Yes & Yes & Yes & Yes & Yes \\
Mean Dependent Variable & Yes & Yes & Yes & Yes & Yes \\
Observations & 0.559 & 0.098 & 0.102 & 0.802 & Yes \\
\hline \hline
\end{tabular}

Notes: ELD stands for ethnolingustic distance. Outcomes in columns (1) through (4) are based on the national censuses and national counts. The outcome in column (5) is based on the school census. All standard errors (in parentheses) are clustered at the municipality level. * $10 \%, * * 5 \%, * * * 1 \%$ significance levels.

\section{REFERENCES}

Anaya Muñoz, Alejandro. 2005. "Democratic Equality and Indigenous Electoral Institutions in Oaxaca, Mexico: Addressing the Perils of a Politics of Recognition." Critical Review of International Social and Political Philosophy, 8(3): 327-47.

Bobonis, Gustavo J., Juan C. Chaparro, and Marco Gonzalez-Navarro. 2021. "Traditional Governance, Ethnic Heterogeneity, and Public Goods Provision in Oaxaca, Mexico." University of Toronto Working Paper.

Burgess, Robin, Remi Jedwab, Edward Miguel, Ameet Morjaria, and Gerard Padró-i-Miquel. 2015. "The Value of Democracy: Evidence from Road Building in Kenya." American Economic Review, 105(6): 1817-51.

Eisenstadt, Todd A. 2011. Politics, Identity, and Mexico's Indigenous Rights Movements. New York, NY: Cambridge University Press.

Hernández-Trillo, Fausto, and Brenda Jarillo-Rabling. 2008. "Is Local Beautiful? Fiscal Decentralization in Mexico." World Development, 36(9): 1547-58.

Holzinger, Katharina, Florian G. Kern, and Daniela Kromrey. 2016. "The Dualism of Contemporary Traditional Governance and the State: Institutional Setups and Political Consequences." Political Research Quarterly, 69(3): 469-81.

Instituto Nacional de Estadística y Geografía. 2010. "Censos y Conteos de Población y Vivienda 1990, 1995, 2000, 2005." INEGI, Aguascalientes.

Juan Martínez, Víctor Leonel. 2013. "What
We Need are New Customs: Multiculturality, Autonomy, and Citizenship in Mexico and the Lessons of Oaxaca." In Latin America's Multicultural Movements: The Struggle Between Communitarianism, Autonomy, and $\mathrm{Hu}$ man Rights. , ed. Todd A. Eisenstadt et al. Oxford, UK: Oxford University Press.

Magaloni, Beatriz, Alberto Díaz-Cayeros, and Alexander Ruiz Euler. 2019. "Public Good Provision and Traditional Governance in Indigenous Communities in Oaxaca, Mexico." Comparative Political Studies, 52(12): 1841-80.

Padró-i-Miquel, Gerard. 2007. "The Control of Politicians in Divided Societies: The Politics of Fear." Review of Economic Studies, 74(4): 1259-74.

Recondo, David. 2001. "Usos y Costumbres, Procesos Electorales y Autonomía Indígena en Oaxaca." In Costumbres, Leyes y Movimiento Indio en Oaxaca y Chiapas. , ed. Lourdes De León Pasquel. Mexico D.F, MX: CIESAS.

Recondo, David. 2007. La Politica del Gatopardo: Multiculturalismo y Democracia en Oaxaca. Mexico D.F, MX: CEMCA-CIESAS.

Secretaría de Educación Pública. 2003. "Censo de Escuelas, Maestros Y Alumnos de Educación Básica y Especial 1990-2002." SEP, Mexico City.

Velázquez Cepeda, María Cristina, and Luis Adolfo Méndez Lugo. 1997. Catálogo Municipal de Usos y Costumbres. Ciudad de Oaxaca, MX: CIESAS/IEE.

Yashar, Deborah J. 2005. Contesting Citizenship in Latin America: The Rise of Indigenous Movements and the Postliberal Challenge. New York, NY: Cambridge University Press. 